Universidade de Brasília

Instituto de humanas

Departamento de Filosofia

Rafael Alves Reis

\title{
Autobiografia como estilo de filosofia
}

\section{Brasília}

2011 


\section{Rafael Alves Reis}

\section{Autobiografia como estilo de Filosofia}

Trabalho de conclusão do curso de filosofia entregue no departamento de filosofia de Brasília para obtenção do título de licenciatura. Sob a orientação do Prof. Dr. Cláudio Araújo Reis

\section{Brasília}




\section{Agradecimentos}

Agradeço primeiramente a minha familía por me ajudar nesses quatro anos de curso. Príncipalmente ao novo irmão Marcos que está ajudando o meu pai a se recuperar.

Em segundo lugar eu agradeço os amigos que encontrei nas minhas caminhadas por essa longa estrada da vida. Desde os amigos da infâncía aos amigos de agora. Com todos vocês eu vivenciei a alegria do compartîthar.

Agradeço de mãos juntas em sinal de reverêncía ao grupo movi-mente e ao seu criador Dhyan Kapish pelas inúmeras experiências de autoconhecimento e diversão.

Agradeço o Prof. Claudio Reis pela paciência e pela compreensão. Por sempre se mostrar disposto a ajudar e a me orientar da melhor forma possivel.

Agradeço a comunidade Jóia do Lótus pela oportunidade que me deram de conhecer a importância de uma família.

Agradeço ao grupo liga da alegria e o grupo Alíança Arco Írís pelos momentos de aprendizado e de celebração da vida.

Agradeço o grupo formação holística do artísta pelas incriveis vivências que tívemos esse ano.

Agradeço o Prof. Júlio Cabrera pela amizade e por mostrar outras maneiras de se fazer fílosofía.

Agradeço as crianças da associação do jardim das flores que me trouxeram muitas alegrías nesse ano. E viva a vida... 


\section{Resumo}

Quais são as razões que influenciam alguns filósofos a escrever a sua autobiografia? Qual é a relação que existe entre a pessoa do filosofo e a filosofia que ele faz? Por que exaltar a própria existência para defender as próprias idéias? Quais são os principais desafios de uma escrita que quer relacionar a memória com a estética de si e a transmissão de idéias? Por que poderíamos considerar obras autobiográficascomo obras filosóficas?

Aqui nessa monografia procuro pensar a relação que existe entre as idéias e as experiências pessoais em autobiografias de filósofos clássicos como Agostinho, Rousseau, Descartes e Nietzsche. Mostrar que é a partir das suas interpretações sobre a existência que eles resolvem escrever e expor as suas principais idéias. Nesses escritos fica claro que existe uma relação entre as suas experiências e as suas idéias. Idéias que possuíram em relação aos problemas que encontraram.

E por meio da analise das causas por de traz das ações que podemos refletir sobre a natureza da filosofia e da prática filosófica. Sobre as condições que levam as pessoas a pensar e desenvolver idéias.

Palavras chave: Autobiografia - Filosofia - Meta-Filosofia 


\section{Sumário}

Introdução

3

Capítulo 1 - A pessoa do filósofo e a sua relação com a filosofia que faz.

1. A relação entre as autobiografias e a cultura..........6

2. A relação entre a vida e a obra .............................8

Capítulo 2 - Por que escrever uma autobiografia? -

1. Por que falar em primeira pessoa?......................13

2. Por que as outras obras não foram suficientes?...22

3. O Pacto autobiográfico e a questão da veracidade das narrações

Capítulo 3 - Conclusões e Desafios.

1. A Gestalt das autobiografias...............................29

2. Questões Meta-filosófica ....................................34

Referências. 39 


\section{Introdução}

Diversos pensadores escreveram sobre as suas experiências querendo mostrar a sua visão acerca dessa misteriosa passagem que é a vida. Esse tipo de gênero literário é conhecido como autobiografia (Escrita da própria vida). Ela é a narração que mostra uma pessoa como ela vê e entende a si mesma.

Diferente da "Biografia"1 e da "Historia de vida"2a autobiografia expõe os acontecimentos que a pessoa quis apresentar. Possui diferenças na maneira em como a trajetória de vida é elaborada e apresentada. É uma seleção que possui causas para sua execução e que procura transmitir a mensagem da pessoa. Mostra as suas decisões sem os acréscimos de um pesquisador ou de um entrevistador.

Uma autobiografia não é direcionada pelas intenções do biografo ou de um entrevistador como na "Biografia"ou na "História de vida". Nela, encontramos características da intimidade e dos processos das escolhas que na maioria dos casos não encontramos em biografias e histórias de vida.

Quando escrevemos sobre a nossa existência nós recriamos uma narração para orientar a explicação dos acontecimentos. De acordo com Philippe Lejeune ${ }^{3}$, uma autobiografia sempre cria seus problemas e os oferece ao seu leitor. Nela o autor escreve suas experiências mostrando os seus problemas, suas dúvidas e as suas decisões. Sua existência é lembrada para mostrar o seu conteúdo e para se recriar por meio dele.

Contardo Calligaris em seu artigo "Verdades de Autobiografias e Diários Íntimos" fala o seguinte sobre isso:

Em um brilhante ensaio, Elisabeth Bruss (1976) propõe a melhor solução para esse debate. Ela considera qualquer produção autobiográfica moderna seja, como um performativo, no sentido de Austin. O sujeito que fala ou escreve sobre si, portanto, não é o objeto

\footnotetext{
${ }^{1}$ É a história de uma pessoa escrita por outra. Gênero literário que começou a ser desenvolvido na antiguidade a partir das obras de Plutarco.

${ }^{2}$ É a narração de pessoa sobre sua vida em uma entrevista. Nela o entrevistador coloca questões de controle para guiar a narração.

${ }^{3}$ Um dos maiores pesquisadores em autobiografias da contemporaneidade. Atualmente ele vem reunindo intelectuais da Europa para aumentar a pesquisa sobre esse assunto: Para maiores informações consulte o seu site: http://www.autopacte.org/index.html
} 
(re)presentado por seu discurso reflexivo, mas tampouco é o efeito, por assim dizer, gramatical de seu discurso. Falando e escrevendo, literalmente, ele se produz.

Narrar-se não é diferente de inventar-se uma vida. Ou debruçar-se sobre sua intimidade não é diferente de inventar-se uma intimidade. $O$ ato autobiográfico é constitutivo do sujeito e seu conteúdo. ${ }^{4}$

São diversos os estilos de autobiografias estudados hoje em dia. Eles vão desde diários e memórias até ficções e correspondências. São preciosas descrições sociais e psicológicas pelo fato de que encontramos nelas características da vida singular e coletiva. Em seu artigo "O relato biográfico como fonte para a história" (2000) Marly Silva mostra o seguinte:

Também favoreceu o boom das biografias e das autobiografias o fato de terem se transformado em um tipo de fonte bastante atraente para os historiadores e cientistas sociaisespecialmente aqueles filiados à história social voltada para o coletivo e o cotidiano -, uma vez que, através da técnica oral, puderam se revelar uma importante via de acesso aos "despossuídos", abrindo a perspectiva de dar voz aos figurantes mudos da história, de tornar "eu" quem era ninguém. ${ }^{5}$

Na história da filosofia encontramos muitas autobiografias que marcaram períodos históricos. Narrações que são consideradas como preciosas obras literárias e filosóficas. Como é o caso das "Confissões" de Santo Agostinho ${ }^{6} \mathrm{e}$ de Rousseau ${ }^{7}$. Obras que são classificadas em nossos dias como modelos de autobiografias.

Para Silva, as biografias e as autobiografias são uns dos pilares do processo complexo de construção das nações:

As biografias e as autobiografias, terreno onde campeavam os "escreventes de historietas", forma o alvo preferencial dos ataques à história política. Gênero historiográfico por excelência do século XIX vinculou-se, por um lado, a certo exercício apologético dos heróis nacionais, sendo considerado, por isso mesmo, um dos pilares do complexo processo de construção das nações. Ao mesmo tempo, filiou-se à concepção da história como "mestra da

\footnotetext{
4 Calligaris - Pág. 49

5 Silva - Pág. 11

${ }^{6}$ Em 397 Santo Agostinho pública as suas confissões inaugurando para anossa cultura esse novo tipo de gênero literário.

${ }^{7}$ Em 1770 Rousseau pública as suas confissões marcando a forma moderna da autobiografia romântica.
} 
vida", segundo a qual seria impossível, e mesmo desejável, tomar essas biografias como modelos exemplares a serem seguidos. ${ }^{8}$

Aqui nessa monografia procuro verificar a co-relação que existe entre a vida e a obra por meio de autobiografias de conhecidos filósofos. Mais precisamente o caso de Agostinho, Rousseau, Descartes e Nietzsche ${ }^{9}$. É a partir da própria existência que eles começam escrever e a expor suas idéias. Esses escritos reforçam a idéia de que existe uma co-relação entre as suas experiências e as idéias que possuíram em relação aos problemas que encontraram.

Verifico se as escolhas, as perdas, o tempo que marca a pele e os impulsos corporais são fatores que influenciam os seus pensamentos e as suas obras. Quero saber também porque as outras obras que escreveram não foram suficientes para apresentar suas idéias?E qual éa reivindicação que eles procuram fazer quando escrevem sobre as próprias memórias ${ }^{10}$ ?

Meu propósito com essas questões é o de verificar se é possível considerar obras autobiográficas como obras filosóficas por serem autobiográficas. Filosóficas porque possuem uma posição frente à existência. Certa interpretação da existência.

E a partir daí verificar qual é o "caráter" da filosofia. Se considerarmos que a autobiografia é um estilo de se fazer filosofia, que mostra o testemunho e a interação entre a pessoa e o mundo (como um estilo que procura uma objetividade), qual seria então a demarcação do que é e o que deixa de ser um estilo filosófico?

\footnotetext{
${ }^{8}$ PÁG. 5

${ }^{9}$ Poderia falar aqui de autobiografias de outros filósofos. Como por exemplo: "As Palavras" de Sartre, "Os diários íntimos" de Kierkegaard, o "Bodenlos" de VilémFlusser, os "Ensaios" Montaigne, "O diário metafísico" de Marcel, etc. Só que creio que seria muito cansativo ver todas essas obras em um trabalho que possui só um semestre para sua conclusão. Fica ai então a possibilidade de levar esse desafio para um futuro projeto de mestrado.

${ }^{10}$ E no caso dos filósofos essas perguntas ganham mais importância porque levamos em consideração que eram pessoas que pararam para refletir sobre a condição humana.
} 


\section{- Capítulo 1 -}

\section{A pessoa do filósofo e sua relação com a filosofia que faz.}

\section{A relação entre as autobiografias e a cultura.}

Uma vez conhecidas as circunstâncias para a criação de urna autobiografia e principalmente o quadro social de sua constituição passa-se, então a classificá-la como expressão da intencionalidade de mostrar determinada imagem de si ao público ${ }^{11}$.

Elas mostram a seqüência de experiências escolhidas onde o indivíduo expressa seus sentimentos e ações em uma cultura. É a elaboração de uma existência que se encontra em um meio social.

De acordo com Silva, as obras autobiográficas fizeram com que os "Quadros Sociais" fossem melhor apresentados:

De outro lado, deu-se o desenvolvimento de uma corrente de estudos na área da história e da antropologia que enfatiza a importância da memória como elemento fundamental da relação entre o individuo e a sociedade, a memória coletiva. Funcionando como um deposito onde o individuo busca elementos que the permitem identificar-se social e historicamente, a memória coletiva funda-se não apenas na comunhão de símbolos e significados compartilhados com a sociedade, como se atualiza nas vivencias individuais e particulares. Ou seja, se, por um lado, o indivíduo só pode ter memória do seu passado como um ser social, por outro, há que se levar em conta o aspecto individual dessa memória. ${ }^{12}$

As práticas pessoais são incluídas em uma época com costumes e valores que marcam a formação da pessoa. Existe uma inter-relação entre a pessoa e o seu contexto cultural. As autobiografias narram como essa interrelação acontece, como segue Silva:

\footnotetext{
${ }^{11}$ PEREREIRA, Ligia Maria Leite. Algumas reflexões sobre histórias de vida, biografias e autobiografias

${ }^{12}$ Silva - " O relato biográfico como fonte para a história"Pág. 16
} 
A relação entre a vida individual e o contexto histórico era outro ponto delicado, e em torno do qual os historiadores freqüentemente divergiam. O método autobiográfico teve uma importante contribuição para essa discussão, na medida em que quebrou o esquematismo simplista, ao desvendar as relações entre o ator individual - e seus vários graus de liberdade de agir - e a rede histórica - e seus vários graus de atividade condicionante. ${ }^{13}$

Podemos encontrar nelas os problemas filosóficos da sua época; os conhecimentos que as escolas ofereciam e os principais problemas da sociedade. Conseguimos encontrar elementos importantes sobre como as pessoas se comportavam e quais eram os seus principais costumes, porque elas mostram aspectos do cotidiano e da intimidade das pessoas.

Nas quatro autobiografias que são estudadas ${ }^{14}$ aqui, eu verifiquei que elas oferecem informações em referência à cultura do autor. E mostra os principais problemas que ele observou na sua época.

Ao escrever a sua autobiografia, a pessoa se coloca (consciente ou inconscientemente) como um representante da sua época. É criação de seu período e ao mesmo tempo uma pessoa especifica que vivencia experiências próprias. Ela quer se exaltar para legar a sua visão em relação a sua pessoa e o seu meio cultural.

O problema que existe em classificar essas obras como referência de contextos culturais é que podemos acabar em meio a abordagens redutoras. Podemos correr o risco de cair no historicismo, no psicologismo e no sociologismo.

As autobiografias também trazem informações importantes sobre a interpretação filosófica que a pessoa possuía da existência e sobre a relação que ela possui com os seus feitos e as suas obras.

\footnotetext{
13 IBD - Pág 10

14 "Confissões" de Agostinho de Hipona;"Discurso do Método", de descartes; "Confissões", De Rousseau, "Ecce Homem" de Nietzsche.
} 


\section{A relação entre a vida e a obra}

"É certo que a vida não explica a obra, mas certo também que elas se comunicam. A verdade é que esta obra a ser feita exigia esta vida."

Merleau-Ponty ${ }^{15}$

No Ecce Homo encontramos a seguinte afirmação de Nietzsche: " Uma coisa sou eu e outra são os meus escritos" ${ }^{\prime 16}$. Nesse pequeno trecho ele separa a sua pessoa das suas obras e mostra que não é possível conhecê-lo por meio delas. É claro que não podemos conhecer uma pessoa dessa maneira, pois sabemos que a sua vida vai para além de suas obras. Jamais iremos encontrar as principais características da sua personalidade em suas obras. Mesmo no caso das autobiografias ${ }^{17}$.

Só que eu acredito que não seja possível separá-las ou olhar para elas como coisas autônomas. Uma obra filosófica não é escrita por acaso. A pessoa e as suas obras estão conectadas. Existe uma relação entre a obra e a pessoa que a escreveu. E essa relação é alimentada pelas experiências.

Foi necessária a minha existência para que essa monografia fosse escrita. Ela de alguma maneira possui informações em relação a minha pessoa. E eu possuo razões para querer escrevê-la. Estamos caminhando juntos nesse momento e eu posso considerar que essa é uma experiência marcante. Não dá para separá-la da minha existência assim como não dá para separar o Emílio de Rousseau ou o Assim Falava Zaratustra de Nietzsche.

A obra corre em paralelo com a existência do seu autor. Possui informações sobre os interesses dele e dicas importantes em relação às possíveis experiências que ele possa ter vivenciado. Ela mostra as suas

\footnotetext{
${ }^{15}$ Maurice Merleau Ponty "O olho e o espírito". Cosaf \& Naify. Pág. - 136

${ }^{16}$ ECCE HOMO - Pág. 42

${ }^{17}$ Lembrando que a pessoa que a escreveu teve controle sobre os registros que queria apresentar. É uma seleção direcionada.
} 
preocupações, suas obsessões e seus desejos em relação ao assunto que é elaborado. Por elas podemos inferir a personalidade do seu autor e pelas experiências dele podemos encontrar a sua razão de existir.

Nas Confissões de Rousseau podemos ver que a educação, a política e a religião são preocupações recorrentes, que ele frequentemente examina em diferentes contextos e situações. Suas principais obras: o Emílio e O contrato social são consequências não só do seu interesse por esses assuntos como também de suas experiências com eles. Percebemos que desde jovem ele fica insatisfeito com a educação da sua época e percebe que a sociedade separa as pessoas ao invés de unir. Ele vivencia os desafios que a pobreza e a indiferença social criam por causa da desigualdade. Suas obras são marcadas por suas experiências e é por elas que ele procura reclamar. Ao ler as Confissões conseguimos ver a sua preocupação em mostrar as injustiças e desigualdades que encontrou em seu caminho. Não é possível negar que as suas obras foram marcadas por suas experiências:

Só, estrangeiro, isolado, sem apoio, sem família, preso apenas aos meus princípios e aos meu deveres, seguia intrepidamente o caminho reto, sem lisonjear, sem manobrar ninguém, às expensas da justiça e da verdade. ${ }^{18}$

Certamente era sofrer ver-se reduzido a passar as noites na rua, e isso muitas vezes me aconteceu em Lyon. Preferia empregar alguns soldos que me restavam para pagar comida a dormida, porque, afinal de contas, eu me arriscava menos a morrer de sono do que de fome. E o que é admirável é que nesse cruel situação não em sentia nem inquieto e nem triste. Não tinha o menor cuidado com o futuro e esperava s respostas que Srta.du Châtelet deveria receber, dormindo a luz das estrelas, estirado por terra ou em cima de um banco, tão tranquilamente como se estivesse em um leito de rosas. ${ }^{19}$

É singular que, com bastante compreensão, embora, nunca aprendi nada com professores, exceto meu pai e o Sr. Lambacier. O pouco que sei aprendi-o só, como veremos depois. Meu espírito, que se impacienta com qualquer espécie de julgo, não se pode sujeitar à lei do momento. O próprio medo de não aprender me impede de estar atento. Com receio de impacientar quem me fala, finjo que compreendo, a pessoa segue adiante e eu não

\footnotetext{
18 "Confissões" - Rousseau - PÁG. 445

19 IBD - Pág. 171
} 
compreendo nada. Meu espírito que caminhar aos eu modo e não se pode submeter ao modo de outrem. ${ }^{20}$

Em Agostinho encontramos a mesma situação. Sua obra-prima dogmática filosófica $A$ trindade ${ }^{21}$ e sua obra apologética $A$ cidade de Deus ${ }^{22}$ não seriam escritas se a sua conversão ao cristianismo não ocorresse. Foi a partir da suas experiências intelectuais e religiosas que ele procurou escrever e apresentar as suas idéias. A suas experiências na vida permitiram que ele refletisse sobre o seu comportamento e sobre as suas as decisões. E foi no cristianismo que ele encontrou o sentido para escrever as suas obras e a se confessar:

RECEBI O sacrifício das Confissões, por meio do ministério da minha língua, por Vós formada e que impelistes a confessar o vosso nome. Sarai todos os meus ossos, e que eles clamem:" Senhor quem há semelhante a Vos? ${ }^{23}$

DURANTE ESSE período de nove anos, desde os dezenove até aos vinte e oito, cercado de muitas paixões, era seduzido e seduzia, era enganado e enganava: às claras, com as ciências que chamam liberais, e às ocultas, sob o falso nome de religião. Aqui ostentava-me soberbo, além supersticioso, e em toda parte vaidoso...

... Permiti-me, eu Vo-lo peço, e concedei-me que percorra com memória fiel os desvios passados dos meus erros, "imolando-Vos uma vitima de louvor". ${ }^{24}$

As obras de Descartes mostram a sua posição cética em querer se livrar de todo conhecimento adquirido que não fosse bem fundamentado. Podemos ver isso no Discurso sobre o método. Ele mostra que as suas experiências intelectuais não o satisfizeram e por causa delas ele resolve escrever como, por exemplo:

Desde a minha infância, estive familiarizado com letras; e como fui levado a acreditar que pela sua ajuda poderia ser adquirido um conhecimento claro e certo de tudo útil a vida, eu ardentemente desejava instrução. Mas assim que terminei o curso inteiro de estudo, ao final do qual é habitual ser admitido à ordem dos instruídos, mudei completamente minha opinião. Porque achei-me envolvido em muitas dúvidas e erros que em convenceram que eu não tinha

\footnotetext{
${ }^{20}$ IBD - Pág. 182

${ }^{21}$ Obra em que Agostinho mostra a suas idéias sobre a santa trindade

${ }^{22}$ Obra em que Agostinho mostra a diferença entre acidade dos homens e a cidade Deus

23 "Confissões" - Agostinho - pág. 123

${ }^{24}$ IBD - Pág.99
} 
avançado mais em todas as minhas tentativas de aprender, que pela descoberta a toda volta de minha própria ignorância. ${ }^{25}$

Nietzsche procura a saúde ao invés da salvação porque ficava frequentemente doente. Sua filosofia é influenciada por suas experiências com as doenças que sofreu e com a solidão que vivenciou:

Um ser tipicamente mórbido não pode ficar são, ao contrário, menos ainda curar-se a si mesmo; para alguém tipicamente são, ao contrário, o estar enfermo pose ser até um enérgico estimulante ao viver, ao mais viver. De fato, assim me aprece agora aquele longo tempo de doença: descobri a vida e a mim mesmo como que de novo, saboreei todas as boas e mesmo pequenas coisas, como outros não as teriam sabido saborear - fiz da minha vontade de saúde, de vida a minha filosofia... ${ }^{26}$

Filosofia, tal como agora entendi e vivi, é a vida voluntária no gelo e nos cumes - a busca de tudo o que é estranho e questionável no existir, de tudo o que a moral até agora baniu. ${ }^{27}$

Quando o filosofo escreve a sua autobiografia ele procura conectar as suas experiências com a filosofia que ele ensina. E isso só ocorreu por causa das suas experiências. O experenciado e o vivido possuíram a capacidade de levá-los a filosofar. Existe uma relação entre as experiências das pessoas e as suas obras. As nossas experiências são as estruturas para as nossas ações.

O legado de um filosofo é fruto da conexão entre as inúmeras escolhas que ele fez em relação às suas experiências. Mas o que significa legar? Geralmente as pessoas legam o resultado feito e não o processo de como se faz. Mas será que só importa o resultado e não o processo? Parece que para quem escreve autobiografia o "como" importa mais. Nela encontramos as circunstâncias que levaram a pessoa a fazer o que fez. Porém, não podemos olhar para essas obras somente como obras referenciais, ou seja, como obras que são guias para explicar o processo de criação das outras obras do autor.Nelas encontramos outras informações interessantes que estão além da explicação. Elas são muito mais do que obras que só indicam os processos de escolhas e decisões.

\footnotetext{
25 "Discurso sobre o método" - Pág. 15

26 "Ecce Homo" - Pág. 25

${ }^{27}$ IBD - 18
} 
Essas relações entre o vivido e o pensado, no entanto, são complexas e envolvem hipóteses factuais que exigiriam um tipo de controle que foge ao alcance desta monografia. Aqui estaremos mais interessados na obra autobiográfica (na autobiografia como obra, como trabalho, como elaboração intelectual) do que, propriamente, nos elementos biográficos e seus eventuais efeitos na constituição de uma filosofia em particular. 


\title{
Capítulo 2
}

\section{Por que escrever uma autobiografia?}

\section{Por que falar em primeira pessoa?}

\author{
"Confessarei, pois, o que sei de mim, e \\ confessarei também o que de mim ignoro, pois \\ o que sei de mim, só o sei porque Vós me \\ iluminais; e o que ignoro, ignoro-lo-ei somente \\ enquanto as minhas trevas se não \\ transformarem em meio-dia, na vossa \\ presença."
}

Santo Agostinho ${ }^{28}$

Quais são as causas que levam uma pessoa a querer escrever em primeira pessoa? Por que ela quer expor a sua história?

Acho que essas são as primeiras perguntas que precisaríamos fazer em relação aos escritos autobiográficos. Uma pessoa que escreve sua autobiografia quer passar uma informação (Seja ela qual for) para os seus leitores. $E$ é por isso que eu acredito que seja importante levar em consideração essas duas questões. Ainda não conheço nenhuma autobiografia que não possua uma causa para sua execução e que não queira passar uma mensagem.

De acordo com Calligaris essas causas são as mais variadas possíveis:

Diários íntimos e autobiografias são escritos por motivos variados: respondem a necessidades de confissão, de justificação ou de invenção de um novo sentido. Freqüentemente, alias, esses três aspectos se combinam. ${ }^{29}$

\footnotetext{
28 "Confissões" - Santo Agostinho - Pág. 263

29 "Verdade de Autobiografias e Diários Íntimos" - Pág. 43
} 
A necessidade de se confessar ou de se justificar é facilmente encontrada nesses escritos. Enquanto lia as autobiografias de Agostinho, Rousseau, Descartes e Nietzsche eu não deixei de verificar que eles estavam preocupados em mostrar as circunstâncias que os levaram a escrever sobre as suas vidas.

Essas preocupações eram as causas (Motivação) da reivindicação que eles queriam passar nessas narrações. A mola que impulsionou a ação de escrever sobre as suas trajetórias.

Para ilustrar essas afirmações irei mostrar agora momentos em que essa preocupação aparece nessas autobiografias. Levando em consideração, é claro, que a minha idéia aqui é a de usá-las como referência para pensar sobre o estilo autobiográfico e não para ficar resolvendo os seus problemas internos.

Rousseau escreve o seguinte sobre isso:

Só tenho um guia fiel com o qual eu posso contar: é o encadeamento dos sentimentos que marcaram a sucessão do meu ser, e por eles os acontecimentos que foram seus efeitos ou suas causas. Esqueço facilmente a desgraça; mas não posso esquecer meus erros, e esqueço ainda menos meus bons sentimentos. A lembrança deles me é muito cara para se possam jamais apagar do coração. Posso fazer omissões nos fatos, transposições, erros de datas; mas não posso me enganar sobre o que senti nem sobre o que os sentimentos me levaram a fazer. E é isso o mais importante. Eo verdadeiro objetivo das minhas confissões é fazer conhecer exatamente o meu íntimo em todas as situações da vida. Foi a história da minha alma que prometi; e para escrevê-la fielmente não preciso de outras memórias. Basta-me como fiz até agora, penetrar em mim mesmo... ${ }^{30}$

Aqui vemos a preocupação que Rousseau possuía em mostrar o que era importante para ele - os seus sentimentos. Se prestarmos atenção podemos ver que existe uma afirmação implícita aí nesse parágrafo: A de querer mostrar que se confessa para esclarecer as causas (sentimentos) que influenciaram as suas decisões.

${ }^{30}$ Confissões - Rousseau- Pág. 260 
Mais adiante, quando Rousseau mostra o momento em que decide 31 escrever a sua autobiografia, conseguimos ver claramente a importância que ele dá à decisão de expor os seus sentimentos:

Não sei por que fantasia, Rey me pedia havia muito tempo que escrevesse as memórias da minha vida. Embora, até então, não fossem muito interessantes pelos fatos, senti que poderiam chegar a o ser pela franqueza que eu nelas poria; e resolvi fazer uma obra única, de uma veracidade sem exemplo, a fim de que pelo menos uma vez, se pudesse ver um homem tal como ele é interiormente. ${ }^{32}$

Sua intenção era a de mostrar aos outros a pessoa que ele foi. Demonstrar o olhar e o entendimento que ele possuía sobrea sua pessoa:

Minhas confissões não são feitas para aparecem enquanto eu for vivo em enquanto viverem as pessoas nelas interessadas. Se eu fosse o senhor do meu destino e do destino deste escrito, ele só veria o dia muito tempo depois da minha morte. Mas os esforços a que o pavor da verdade obriga meus poderosos opressores para lhe apagarem os traços dão-me, para conservar, a liberdade de usar tudo que me permitem o direito mais estrito e a mais severa justiça. Se minha memória se devesse extinguir comigo, em vez de comprometer alguém, eu suportaria sem murmurar um opróbrio injusto e passageiro; mas, já que meu nome deve viver, devo procurar transmitir com ele a lembrança do homem infortunado que o usou, tal como ele viveu realmente, e não tal como os inimigos injustos o procuram incessantemente pintar, $^{33}$

Ao ler as suas Confissões nós conseguimos ver que a sua vida foi marcada por muitos conflitos e perseguições. Principalmente após ter assinado o livro Emílio $^{34}$. Rousseau passou por inúmeras dificuldades e foi forçado a fugir para não ser preso. Sua reclamação está relacionada às criticas que sofreu. No final do décimo segundo livro das Confissões ele escreve o seguinte:

Disse a verdade, se alguém sabe de coisas contrárias ao que acabo de expor, fossem elas mil vezes provadas, só sabe de mentira e imposturas; e se essa pessoa se recusar a esclarecê-las e aprofundá-las enquanto eu ainda estou vivo, é porque não aprecia a justiça nem a verdade. Quanto a mim, declaro em alta voz e se receio: os seus próprios olhos o que

\footnotetext{
${ }^{31}$ Em 1764 ele recebeu um panfleto anônimo, "O sentimento dos cidadãos", acusando-o de hipócrita, pai desnaturado e amigo ingrato. Foi escrito por Voltaire, e seu efeito sobre Rousseau foi terrível. E por causa desse panfleto ele resolve escrever a sua autobiografia.

32. Confissões - Rousseau- Pág. 464

33 IBD. Pág. 364

${ }^{34}$ Depois que assinou esse livro Rousseau começoua ser alvo de invejas e abusos e teve que deixar a frança. Essa perseguição começa na pág.518.
} 
eu sou naturalmente, examine o meu caráter, meus costumes, minhas inclinações, meus prazeres, meus hábitos, e possa ainda assim julgar-me um homem desonesto, é um homem que deve ser suprimido. ${ }^{35}$

Podemos ver que a necessidade de se justificar em relação às críticas foi a necessidade que o levou a escrever. Ele fala em primeira pessoa porque queria vindicar-se contra o desagravo e a injúria de seus inimigos. Para isso foi preciso mostrar a sua visão pessoal dos acontecimentos. Contar o seu lado da história.

O caso de Santo Agostinho ${ }^{36}$, que nasceu 1358 anos antes que Rousseau, não é tão diferente. Sua autobiografia possui o mesmo título, Confissões, e através dela ele quer mostrar seus sentimentos para esclarecer as causas que influenciaram as suas escolhas. A diferença que existe entre essas duas confissões é a de que Agostinho aparentemente procura guiar suas palavras a Deus ao invés de para as outras pessoas (Como é o caso de Rousseau):

Que tenho eu que haver com os homens, para que me ouçam as Confissões, como se houvesse de me curar das minhas enfermidades? Que gente curiosa para conhecer a vida alheia e que indolente para corrigir a sua! Por que pretendem que thes declare quem sou, se não desejam também ouvir de Vós que eles são? Ouvindo-me falar de mim, como hão de saber que lhes declaro a verdade, se ninguém "sabe o que se passa num homem, a não ser o espírito desse homem que nele habita"? Se, porém, Vos ouvem falar a seu respeito, não poderão dizer: "Nosso Senhor mente". Com efeito, o ouvirem-Vos falar a seu respeito, que é senão conhecerem-se a si mesmos? E quem há que, conhecendo-se, diga sem mentir: "é falso"? " A caridade tudo crê", sobretudo entre os que ela unifica, ligando-os entre si. Por isso também eu, Senhor, me confesso a Vós, para que os homens, a quem não posso provar que falo verdade, me ouçam. Mas aqueles a quem a caridade abre em meu proveito os ouvidos acreditam em mim. ${ }^{37}$

Nessas confissões a figura de deus fica entre Agostinho e os seus leitores. Ele aparece sem parar em todos os parágrafos como o seu ouvinte fiel. Quem lê as Confissões vê claramente que Agostinho está embriagado por seu Deus. Ele o classifica como aquele que o conhece inteiramente e que participa das suas ações boas:

\footnotetext{
${ }^{35}$ Confissões - Rousseau -Pág. 591

36

${ }^{37}$ Confissões - Agostinho -Pág. 262
} 
Senhor, conheceis-me tal como sou. Já vos disse com que fruto me vou confessando a Vós. Não Vos faço esta confissão com palavras e vozes de carne, mas com palavras da alma e gritos do pensamento, que vossos ouvidos já conhecem. Quando sou mau, o confessar-me a Vós é o mesmo que desagradar-me a mim próprio; porém, quando sou bom, o confessar-me a Vós só significa que não atribuo nada a mim, porque abençoais, Senhor, o justo mas antes faço na vossa presença é e não é em silêncio. É em silencio quanto às palavras; mas é em clamor quanto aos afetos. Nenhuma verdade digo aos homens que Vós já antes ma não tenha ouvido. Nem me ouvis nada já antes mo não tivésseis dito. ${ }^{38}$

Agostinho escreve as suas confissões como se estivesse se declarando para Deus. Sua intenção era de confessar para ele os seus erros. Só que eu creio que não podemos apoiar a ideia de que as suas reflexões são exclusivamente direcionadas para ele. Podemos ver claramente que Agostinho está preocupado em mostrar a sua fé para as outras pessoas. Para que eles caminhem na mesma direção que ele:

Querem ouvir-me; mas com que fruto? Desejarão congratular-se comigo, ouvindo quanto a vossa graça me aproximou de Vós? Desejarão orar por mim, sabendo quanto o peso dos meus pecados me faz atrasar (na virtude)? Bem, mostrar-Ihes-ei quem sou. Não é pequeno fruto, Senhor meu Deus, que muitos vos rendam graças por mim e que numerosas pessoas Vos implorem em meu favor. Oxalá que o coração dos meus irmãos ame, em mim, o que ensinais a amar, e igualmente aborreça o que ensinais a aborrecer.

Que isso brote de um coração fraterno, não de um coração estranho, nem de filhos espúrios " cuja boca falou vaidade e cuja direita é mão de iniqüidade. Faça isso um coração fraterno que se alegre comigo quando me aprova e se entristeça quando me desaprova, porque igualmente me ama, quer me aprove, quer me desaprove. A estes é que me revelarei: respirem eles nas minhas ações boas e suspirem nas más. As ações boas são obras e dons vossos; as más são delitos meus e juízos vossos. Respirem nas ações boas e suspirem nas más. Subam à vossa presença hinos e lágrimas destes corações fraternos que são "os vossos "turíbulos". 39

O que ele quer é alcançar o conhecimento de sua pessoa por meio das confissões. E por isso ele expõe o valor da sua fé:

Fazei que eu vos conheça, ó conhecedor de mim mesmo, sim, que vos conheça como de vós sou conhecido. Ò virtude da minha almaentrai nela adaptai-a Vós, para a terdes e possuirdes sem mancha nem ruga. É esta a esperança com que falo, a esperança em que me alegro quando gozo de uma alegria sã. Os outros bens desta vida tanto menos se deveriam

\footnotetext{
${ }^{38}$ IBD - Pág 260

${ }^{39}$ IBD. Pág. 262
} 
chorar quanto menos mais os choramos; e tanto mais se deveriam chorar quanto menos os choramos. Mas Vós amastes a verdade, pelo que quem a pratica alcança a luz. Quero-a também praticar no meu coração, confessando-me a Vós, e, nos meus escritos, a um grande número de testemunhas.

Embora ele classifique os seus leitores como "testemunhas" da sua pratica religiosa vemos que é por meio desse testemunho que ele quer passar a sua mensagem de salvação para que as outras pessoas possam encontrar a mesma alegria e admiração que ele possuía por seu Deus:

O fruto das minhas confissões é ver, não o que fui, mas o que sou. Confesso-Vos isto, com intima exultação e temor, com secreta tristeza e esperança, não só diante de Vós, mas também diante de todos que crêem em Vós; dos que participam da mesma alegria e, como eu, estão sujeitos à morte; dos que são meus concidadãos e peregrinam neste mundo; e enfim, diante dos que me precedem, me seguem ou me acompanham no caminho da vida. Estes são os vossos servos, os meus irmãos, aos quais constituísses vossos filhos e vossos senhores. A eles me mandaste servir, se quiser viver de Vós e convosco. ${ }^{40}$

É uma autobiografia religiosa que quer passar uma mensagem apologética. Santo Agostinho quer mostrar o caminho para a salvação. Ele fala em primeira pessoa porque quer mostrar aos outros, se confessando,a sua transformação pessoal. Deus é intermediário entre a mensagem que ele quer passar e os seus leitores.

René Descartes em sua autobiografia intelectual ${ }^{41}-O$ discurso sobre 0 método ${ }^{42}$ - fala sobre a sua intenção em escrever os seus caminhos intelectuais no seguinte trecho:

Meu desígnio presente, então, é não o de ensinar o método que cada um deve seguir para a conduta certa da sua razão, mas somente descrever o modo pela qual tentei dirigir minha própria. Os que se firmaram em dar preceitos devem se considerar possuidores de maior habilidade do que os a quem prescrevem; e se erram no detalhe mais leve, eles se sujeitam a se censurados. Mas como este tratado somente é avançado como uma história, ou, se você preferir, como um conto no qual, entre alguns exemplos merecedores de imitação, lá serão ${ }^{43}$

\footnotetext{
40 IBD- 262

41 Uma autobiografia que narra somente o percurso intelectual da pessoa sem fazer referência a outras extensões da sua existência. 42

43 O discurso sobre o método - Pág. 14
} 
Foi a sua posição cética que o possibilitou procurar as suas próprias respostas em relação aos problemas filosóficos que encontrou. Depois de passar por várias escolas e de viajar por vários países a procura de conhecimentos indubitáveis ele percebeu que conseguiria criar o seu próprio método filosófico. Foi por causa do seu mal estar cognitivo que ele resolveu dar início (em certo sentido) a uma nova forma de filosofar com bases gnosiológicas $^{44}$ :

Por estas razões, assim que minha idade permitiu-me sair do controle de meus instrutores, abandonei inteiramente o estudo de letras e não resolvi buscar qualquer outra coisa ciência que o conhecimento de mim mesmo, ou do grande livro do mundo. ${ }^{45}$

E é por meio de muitas metáforas ${ }^{46}$ e imagens que ele apresenta a sua preocupação em saber separar a verdade da falsidade para poder encontrar o caminho correto na vida e agirpor ela com confiança.

Descartes fala em primeira pessoa porque quer mostrar aos outros o caminho que fez para chegar ao seu método ${ }^{47}$. A insatisfação com os ensinamentos que adquiriu fizeram com que ele mesmo procurasse um caminho. E esse caminho foi o que ele quis expor no seu discurso. Sua autoridade está em jogo nesse contexto.

E Friedrich Nietzsche logo no prólogo do Ecce Homo escreve o seguinte:

Prevendo que dentro em pouco devo dirigir-me à humanidade com a mais séria exigência que jamais Ihe foi colocada, parece-me indispensável dizer quem sou. Na verdade já se deveria sabê-lo, pois não deixei de "dar o testemunho" de mim. Mas a desproporção entre a grandeza de minha tarefa e a pequenez de meus contemporâneos manifestou-se no fato de que não me ouviram, sequer me viram. Vivo de meu próprio crédito; seria um mero preconceito, que eu viva?... Basta-me falar com qualquer "homem culto"' que venha a Alta Engadina no verão para convencer-me de que não vivo... Nessas circunstâncias existe um

\footnotetext{
${ }^{44}$ Esse método se inicia com um auto-estudo que exclui todas as suas opiniões antigas para encontrar a verdade indubitável. Descarte começa a imaginar que existe um Deus enganador que o ilude e o faz acreditar que suas opiniões acerca do mundo são verdadeiras quando na realidade podem ser truques e ilusões. Chega então o momento que por meio da dúvida ele desconfia da própria existência, e ai então conclui de que do próprio ato de duvidar que é necessariamente pensar, segue-se de forma evidente e clara que ele pensa e existe, e ai então surge a celebre frase: Penso, logo existo. Este é o principio primeiro da filosofia de Descarte, uma regra aplicativa que age por meio da dúvida a fim de encontrar verdades claras e distintas, o seu método para o conhecimento verdadeiro.

${ }^{45}$ Pág18

${ }^{46}$ Veja o início do $2^{\circ}$ capitulo

${ }^{47}$ Seu percurso se encontra no primeiro e no segundo capitulo.
} 
dever, contra o qual no fundo rebelam-se os meus hábitos, e mais ainda o orgulho de meus instintos, que é dizer: Ouça-me! Pois eu sou tal e tal. Sobretudo não me confundam! ${ }^{48}$

Só essa introdução já responde as duas perguntas que foram colocadas no início desse capítulo (Em relação a Nietzsche). Podemos ver claramente que ele escreve sua autobiografia porque queria ser reconhecido. Queria ser lido. Ele estava insatisfeito com a indiferença dos seus contemporâneos em relação a sua pessoa e aos seus escritos:

Uma coisa sou eu, outra são meus escritos. Abordarei, antes de falar deles, a questão de serem compreendidos ou incompreendidos. Faço-o com a negligência mais apropriada pois este não é ainda o tempo para essa questão.Tampouco é ainda o meu tempo, alguns nascem póstumos. - algumdia serão necessárias instituições onde se viva e se ensine tal como entendo o viver e o ensinar: talvez se criem até cátedras para interpretação do Zaratustra. Mas seria completa contradição, se já hoje eu esperasse ouvidos e mãos para minhas verdades: que hoje não me ouçam, que hoje nada saibam receber de mim, é não só compreensível, parece-me até justo. Não desejo ser confundido - para tanto, é preciso que eu mesmo não me confunda. ${ }^{49}$

Sua autobiografia foi escrita para mostrar o seu status como autor. É por isso que nela encontramos uma explicação para cada um de seus livros. Nietzsche procura se arremessar por inteiro ao público para mostrar o que escreveu.

Nessa autobiografia, ele eleva a sua existência ao máximo. Os títulos dos capítulos expõem a vontade que ele possuía em querer se apresentar como uma pessoa extraordinária. ${ }^{50}$

Sua maior preocupação era liberar as pessoas da moral (cristã) por meio da sua filosofia:

Quanta verdade suporta, quanta verdade ousa um espírito? Cada vez mais tornou-se isto para mim a verdadeira medida de valor. Erro (- a crença no ideal-) não é cegueira, erro é covardia... Cada conquista, cada passo adiante no conhecimento é conseqüência da coragem, da dureza consigo, da limpeza consigo... Eu não refuto os ideais apenas ponho luvas diante

\footnotetext{
${ }^{48}$ ECCE HOMO - Pág. 17

${ }^{49}$ IBD. 52

50 Títulos: Por que sou tão sábio. Por que sou tão inteligente. Por que escrevo tão bons livros. Por que sou um destino.
} 
deles...Nitimur in Vetitum:* com este signo vencerá um dia minha filosofia, pois até agora proibiu-se sempre, em principio, somente a verdade. ${ }^{51}$

Fui compreendido? - O que me separa o que me põe a parte de todo o resto da humanidade, é haver descoberto a moral cristã. Para isso era necessária uma palavra que mantivesse o sentido de desafio para cada homem. ${ }^{52}$

Ele fala em primeira pessoa porque quer mostrar as idéias que o levariam a ser conhecido como um mestre da humanidade. Como uma pessoa que poderia revolucionar a nossa cultura:

Conheço a minha sina. Um dia meu nome será ligado a lembrança de algo tremendo de uma crise como jamais houve sobre a Terra, da mais profunda colisão de consciências, de uma decisão conjurada contra tudo o que até então foi acreditado, santificado, requerido. Eu não sou um homem, sou dinamite. ${ }^{53}$

Podemos ver que as "causas" que motivaram esses quatro filósofos a escrever sobre suas vidas são extremamente diferentes: Rousseau quer esclarecer os seus sentimentos em relação às criticas que sofreu; Agostinho se confessa para mostrar o valor da sua fé; Descartes quer mostrar os caminhos que o levaram à criação do seu método e Nietzsche quer ser reconhecido. Só que as necessidades eram semelhantes: Confissão, justificação, esclarecimento e invenção de um novo sentido. Sobretudo, tratava-se de mostrar que o sujeito que fala possui uma "autoridade" para falar de onde fala, autoridade cujo título adquiriu pela singularidade de sua experiência.

Eles falam em primeira pessoa simplesmente porque suas causas são existenciais. Foram marcados pela existência e por isso queriam falar sobre as suas experiências. Para esclarecer a sua pessoa e as suas idéias foi preciso sacrificar a própria história por elas. Sacrifício que não encontramos em outras das suas obras.

\footnotetext{
${ }^{51}$ IBD. 18

52 IBD. 114

${ }^{53}$ Ibd. 109
} 


\section{Por que as outras obras que escreveram não foram suficientes para apresentar a sua filosofia?}

Assim que comecei a ler as Confissões de Agostinho, fiquei curioso em saber a razão pela qual as outras obras que escreveu (A Trindade, Cidade de Deus, etc.) não foram suficientes para apresentar a sua filosofia? ${ }^{54}$.

Foi só depois de encontrar as principais causas que marcaram as suas experiências que eu consegui encontrar respostas para essa pergunta:

Agostinho escreveu uma autobiografia porque queria usar a sua existência como argumento para as suas idéias. Quis usar a si mesmo como exemplo. E isso também vale para os outros filósofos que escrevem sobre suas vidas.

Creio que eles escrevem a sua autobiografia porque queriam passar uma mensagem em relação aos seus ideais. Elas não são meras apresentações de uma pessoa. Nem são dicionários que mostram o significado das suas ações. Por elas eles queriam mostrar as suas vidas a favor das suas filosofias. O propósito deles não era só o de se apresentar mas o de mostrar o que pensaram e como olharam para as suas vidas por meio desses pensamentos.

Para encontrar sentido para as suas ideias centrais eles apresentaram a sua vida como prova. O exemplo em relação ao que ensinam. Vimos que existem causas que os direcionaram a escrever a sua autobiografia. E que essa causa frequentemente está associada à vivências que singularmente marcaram as suas vidas.

Os problemas que são oferecidos pelas autobiografias não são como os problemas que aparecem em obras teóricas. Nela o autor está envolvido,

\footnotetext{
${ }^{54}$ Levando em consideração que nas suas confissões encontramos três importantes tratados filosóficos O tratado sobre o mal, sobre memória e sobre o tempo.
} 
participa e interage com os seus problemas como o personagem principal da sua trama. Ele não se esconde por detrás da sua filosofia como nas obras teóricas.

As suas outras obras "não - autobiográficas" não foram suficientes porque não possuíam o acréscimo existencial. Não conseguiriam passar as suas mensagens existenciais. Agostinho, nas Confissões, mostra a diferença que existe entre o caminho religioso e o caminho pagão:

Eu pecava, porque em vez de procurar em Deus os prazeres, as grandezas e as verdades, procurava-os nas suas criaturas: em mim e nos outros. Por isso, precipitava-me na dor, na confusão e no erro.

Graças a Vos sejam dadas, minha doçura, minha glória, minha confiança e meu deus! Graças Vos sejam dadas pelos dons que me concedestes. Concervai-mos. ${ }^{55}$

Rousseau mostra a relação que existe entre o homem natural (Que veio virtuoso) e o homem civilizado (Corrompido):

Imagine-se um caráter tímido e dócil na vida ordinária, porem, ardente orgulhoso, indomável, nas paixões; um menino governado sempre pela voz da razão, tratado sempre com doçura, equidade, complacência, que não tinha sequer idéia de injustiça, e que, pela primeira vez sofre uma injustiça tão terrível da parte, precisamente das pessoas que ele mais respeita: que reviravolta de idéias! Que desordem de sentimentos! Que confusão no seu cérebro, no coração e em todo o seu pequenino ser inteligente e moral! ${ }^{56}$

Descartes mostra a diferença que existe entre o caminho seguro que nos leva ao conhecimento verdadeiro e o caminho tradicional adquirido nas escolas:

...E mais adiante, quando considerei o número de opiniões contraditórias que tocam um único assunto que podem ser apoiadas por homens instruídos, enquanto que pode haver apenas um verdadeiro, considerei como bem perto do falso tudo o que fosso só provável. ${ }^{57}$

Além do mais, eu sempre tive um desejo mais sério para saber distinguir o verdadeiro do falso, para que eu pudesse claramente acertar o caminho reto na via, e proceder nela com confiança. $^{58}$

\footnotetext{
55 "Confissões" -Agostinho - PÁG - 60

56 "Confissões" - Rousseau - PÁG. 41

57 "Discurso sobre o método" - Pág. 18

${ }^{58}$ IBD -Pág. 19
} 
E Nietzsche mostra os problemas relacionados à moral e à religião (Lembrando que seu pai era pastor):

E esta é de fato a minha percepção: os professores, os guias da humanidade, teólogos todos, foram todos também décadents: daí a transvaloração de todos os valores em algo hostil a vida, daí a moral... Definição da moral: moral - a indiosincrasia dos décadents, com o culto desígnio de vingar-se da vida - e com êxito: Dou valor a esta definição. ${ }^{59}$

Todos eles procuraram expor a sua filosofia a partir das suas experiências. Eles oferecem os problemas autobiográficos para conseguir mostrar as suas reflexões sobre eles. E para isso foi necessário se sacrificar. Colocar-se no jogo.

Isso mostra que uma autobiografia vai além da mera apresentação dos acontecimentos e dos processos de escolha de ações. Ela é uma obra que também procura passar uma mensagem reflexiva sobre a existência. Procura nos fazer refletir sobre as atividades humanas por meio das narrações que são feitas.

O que resta saber é se essas narrações são verdadeiras ou se são criações ou invenções para encaminhar pensamentos.

${ }^{59}$ Ecce Homo Pág-116 


\title{
3. O pacto autobiográfico e a questão da veracidade.
}

\begin{abstract}
"Quereria poder de algum modo tornar minha alma transparente aos olhos do leitor; e por isso procuro mostrá-la sob todos os pontos de vista, esclarecê-la em todos os dias, proceder de modo que não haja um movimento que ele não perceba, enfim, de jeito que ele julgar por si próprio o principio que produz. "
\end{abstract}

Jean Jacques Rousseau ${ }^{60}$

Lejeune mostra que em qualquer autobiografia conseguimos encontrar um pacto entre o autor e o seu leitor. Esse pacto é conhecido como "O pacto autobiográfico". O rito de apresentação que expõe o compromisso do autor em apresentar o verdade ao seu leitor. É o momento em que o discurso nasce como discurso autobiográfico:

O pacto autobiográfico é o compromisso que leva o autor a contar a sua vida diretamente (ou uma parte ou aspecto de sua vida) em espírito de verdade.

O pacto autobiográfico se opõe ao pacto da ficção. Qualquer um que oferece um romance (Embora seja baseado em sua vida) não pede que você acredite no que ele diz, mas simplesmente para fingir que acredita.

Em uma autobiografia o autorpromete a você que o que vai dizer é verdadeiro, ou pelo menos, o que ele acredita que seja verdade. Ele se comporta como um historiador ou um jornalista, com a diferença de que o assunto sobre o qual ele promete dar informação verdadeira é sobre ele mesmo.

Se você, leitor, sente que o autobiógrafo se esconde ou altera uma parte da verdade, você pode pensar que minto. No entanto, é impossível dizer que um romancista mente: não faz sentido, uma vez que ele não se comprometeu em dizer a verdade. Você pode julgar se o que ele disse é provável ou improvável, coerente ou incoerente, bom ou mau, etc. Mas isso está além da distinção entre o verdadeiro e o falso. ${ }^{61}$

\footnotetext{
60 "Confissões"' - Rousseau - Pág: 179

${ }^{61}$ Texto retirado do site: http://www.autopacte.org/pacte autobiographique.html - visitado pela última vez em $01 / 12 / 11$
} 


\section{Podemos encontrar esse pacto na seguinte passagem das Confissões} de Rousseau:

Dou começo a uma empresa que não tem exemplos, e cuja execução não terá imitadores. Quero mostrar aos meus semelhantes um homem em toda a verdade da natureza; e serei eu esse homem.

Eu só. Sinto meu coração e conheço os homens. Não sou feito como nenhum dos que já vi; e ouso crer que não sou feito como nenhum dos que existem. Se não sou o melhor, sou, pelo menos, diferente. E só depois de ma haver lido é que poderá alguém julgar se a natureza fez bem ou mal em quebrar a fôrma em que me moldou.

Soe quando quiser a trombeta do juízo final: virei, com este livro nas mãos, comparecer diante do soberano juiz. Direi altivo: "Eis o que fiz, o que penseie o que fui. Disse o bem e o mal com a mesma franqueza. Nada calei de mau, nada acrescentei de bom; e se me aconteceu usar algum ornato indiferente, não foi nunca para preencher o vácuo da minha falta de memória... ${ }^{62}$

\section{E nas Confissões de Santo Agostinho:}

Permiti, porém, que "eu, pó e cinza", fale à vossa misericórdia. Sim, deixai-me falar, já que à vossa misericórdia me dirijo, e não ao homem que de mim pode escarnecer. Talvez Vos riais de mim, mas aplacado, compadecer-Vos-eis.

Que pretendo dizer, Senhor meu deus, senão que ignoro donde parti para aqui, para esta que não sei como chamar, se vida mortal ou morte vital? Receberam-me na vida as consolações da vossa misericórdia, como ouvi contar aos pais da minha carne, de quem eem quem me formastes no tempo, que eu nada disto me lembro... ${ }^{63}$

\section{E no Discurso de Descartes:}

Eu sei como estamos sujeitos à ilusão no que se relacionaa nós mesmos, e também quanto aos julgamentos de nossos amigos, eles são suspeitos quando dados a nosso favor. Mas tentarei neste discurso descrever os caminhos que segui, e esboçar minha vida como num quadro, para que cada um também possa julgar dela para si, e que na opinião geral deles entretida, como reunidos no relato atual, posso dar uma ajuda nova para instrução a ser somada aos que tive hábito de empregar ${ }^{64}$

\section{E no Ecce Homo de Nietzsche:}

\footnotetext{
${ }^{62}$ Confissões -Rousseau - Pág.29

${ }^{63}$ Confissões -Agostinho - Pág. 41

${ }^{64} \mathrm{O}$ discurso sobre o método - Pág. 14
} 
Vivo de meu próprio crédito; seria um mero preconceito, que eu viva?... Basta-me falar com qualquer "homem culto"' que venha a Alta Engadina no verão para convencer-me de que não vivo... Nessas circunstâncias existe um dever, contra o qual no fundo rebelam-se os meus hábitos, e mais ainda o orgulho de meus instintos, que é dizer: Ouça-me! Pois eu sou tal e tal. Sobretudo não me confundam! ${ }^{65}$

O pacto acontece como um compromisso em mostrar a sua história da maneira mais verdadeira possível. Seja em relação aos outros ou a si mesmo. Nos quatro casos encontramos a intenção de apresentar a sua história de vida em espírito de verdade. De não deixar dúvidas.

Esse compromisso em falar a verdade sempre foi uma questão crucial para as pessoas que escrevem autobiografias. Isso mostra que realmente existe o propósito de mostrar para o leitor informações verdadeiras sobre a sua existência, ou ao menos informações que procuram se aproximar da verdade: Marly Silva fala o seguinte sobre isso:

Não se trata, pois, de recuperar a história "tal como ela efetivamente ocorreu", mas sim de reconstruí-la através das múltiplas versões veiculadas pelos atores que viveram acontecimentos e conjunturas do passado. ${ }^{66}$

A intenção em narrar o que realmente aconteceu é o que leva algumas pessoas a escrever a sua autobiografia. Mesmo sabendo que a verdade exata seja dificilmente apresentada. Calligaris fala sobre essa questão da seguinte maneira:

Entende-se, aliás, que nesse quadro a sinceridade se separa, até conceitualmente, da verdade e se torna um valor diferente e hierarquicamente superior. Não sei exatamente desde quando é possível no ocidente ser sincero, embora factualmente mentindo. Mas é certo que hoje sabemos apreciar a intenção sincera de quem fala e escreve sua autenticidade, mesmo sabendo, por outro lado, que factualmente o que ele/ela diz ou escreve é falso. Ser sincero, autêntico, é um valor em si, em nada subordinado à verdade factual. ${ }^{67}$

Sabemos que é muito difícil mostrar como ocorreram exatamente as experiências do passado. Frequentemente só conseguimos lembrar os acontecimentos que mais marcaram o nosso espírito. E só lembramos a nossa perspectiva sobre aquilo que aconteceu. E por ela conseguimos alterar a

${ }^{65}$ Ecce Homo - Pág. 17

${ }^{66}$ Silva - "O relato biográfico como fonte para a história"Pág. 12

${ }^{67}$ Calligaris - "Verdade de Autobiografias e Diários Íntimos" - Pág. 45 
lembrança que possuímos em relação a esses acontecimentos. Como continua Calligaris:

É uma verdade que concerne ao sujeito autobiográfico em um passo sempre crucial: o passo que consiste em se dar (De uma só vez ou no dia a dia) significação e consistência. Essa verdade crucial evidentemente não pode ser julgada no tribunal da verdade factual. Omissões, acréscimos, remanejamentos são peças do puzzle do sujeito em um momento do seu fieri. Nesse sentido (um pouco diferente de suas intenções), vale a idéia de Lacan de que a verdade está em uma linha de ficção. Sob a condição de entender que ficcionalizar a própria vida é o jeito ocidental moderno de orientá-la e reorientá-la. P53

Podemos interpretar a mesma experiência de diversas maneiras. Podemos dar muitas orientações para a mesma situação. Mas isso não é importante para o "Pacto autobiográfico". O que importa é a preocupação em sequenciar uma história em acordo com a proposta de se mostrar em verdade (Ou ao menos de se aproximar ao máximo dela). Em mostrar como a formação da pessoa ocorre através da sua retrospectiva.

O pacto entre o autor e seu leitor passa as fronteiras das circunstâncias e entra na sequência que é apresentada na sua história. Isso mostra que é a formação da pessoa que a escreve o que mais interessa. O compromisso do autor com seu leitor em mostrar os acontecimentos que formam uma pessoa. $O$ subjetivo e o objetivo correm de mãos dadas nos acontecimentos apresentadas em autobiografias.

O objetivo do "pacto" não é apenas o de apresentar a verdade concreta e objetiva dos acontecimentos. A interioridade é incluída como a maneira em que esses acontecimentos foram percebidos e registrados. A verdade oscila entre a objetividade do mundo e a subjetividade da pessoa. Dentro da organização que ele fez das próprias experiências. Da sua inter-relação com o mundo. 


\section{- Capítulo 3 -}

\section{Desafios e Conclusões}

\section{A Gestalt das autobiografias}

"Direi ao mesmo tempo uma palavra geral sobre a minha arte do estilo. Comunicar um estado, uma tensão interna de pathos por meio de signos, incluindo o tempo desses signos- - eis o sentido de todo estilo; e considerando que a multiplicidade de estados interiores é em mim extra-ordinária, há em mim muitas possibilidades de estilo - a mais bultifária arte do estilo que o homem já dispôs. "

Friedrich Nietzsche ${ }^{68}$

Nos dois primeiros capítulos nós vimos que uma autobiografia não é somente a apresentação de uma personalidade. Nela o autor procura passar as suas reflexões em relação à existência.

Só que essas reflexões não podem ser compreendidas se só levarmos em conta algumas experiências da pessoa. Eu não conseguirei compreender as reflexões que Rousseau queria passar nas Confissões somente pelo fato de ter encontrado as causas que o levaram a escrever. Ou por analisar o seu comportamento na infância e o comparar com o seu comportamento em outras fases. É preciso ver a sua existência como uma totalidade (Gestalt) para pode organizar os elementos que são apresentados.

Rosenthal, em seu artigo "A estrutura e a Gestalt das autobiografias e suas consequências metodológicas" (1991), afirma que a escrita autobiográfica procurar sintetizar o "eu" por meio da sua inter-relação com o mundo:

\footnotetext{
${ }^{68}$ Ecce Homo. Pág. 57
} 
A ordem que se pode descobrir uma história de vida não é uma construção subjetiva do individuo, nem um simples produto de modelos sociais prefigurados objetivos, nem decorre de idéias ou fatos, mas é ocasionada pela "vida" de experiência do mundo" ( Welterfahrendes Leben), para empregar a expressão de Husserl. È a ordem da inter-relação primordial do "mundo" e do "eu".

Sustento neste artigo a tese de que essa ordem tem a qualidade de gestalt no sentido da teoria da gestalt (Ehrenfels, 1980) e sua interpretação fenomenológica por Aron Gurwitsch.

O significado do conjunto e o de suas partes se constituem mutuamente em gestalten; há uma continua modificação mútua de componentes. Cada parte individual tem uma significação funcional para gestalt, e esse significado se relaciona com as outras partes.

"Escrever sua autobiografia é tentar captar sua pessoa em sua totalidade, em um movimento recapitulativode síntese do eu"69

A construção da subjetividade do indivíduo e os modelos sociais não poderiam captar a síntese do "eu' e do "mundo" que a pessoa queria passar. Para entender essa inter-relação precisamos ver como a pessoa organizou os elementos que encontrou em relação à sua historia. Isso, no entanto, só é possível se levarmos em conta que as suas reflexões são organizações criadas em relação ao que experimentaram. Ou seja, não é o mundo mesmo, mas uma organização própria dos seus elementos.

Isso mostra que as interpretações que podemos ter da existência na verdade são diversas Gestalten construídas a partir da organização que fazemos dos seus elementos. As ideias de Agostinho sobre a existência são diferentes das ideias de Nietzsche. Um procura negar-se para salvar a sua alma $^{70}$ e ou outro procura se exaltar ao máximo para "salvar" a sua existência ${ }^{71}$. A ideia de salvação foi organizada por eles de maneira diferente, mas ainda participa de um mesmo núcleo de significado.

Isso mostra que as reflexões sobre a existência querem apresentar um significado. E esse significado é passado em autobiografias por meio da observação da pessoa. Aí entra em cena novamente a questão da verdade dos

\footnotetext{
69 " A estrutura e a Gestalt das autobiografias e suas conseqüências metodológicas" - Pág. 196

${ }^{70}$ Referência

${ }^{71}$ Referência0
} 
acontecimentos. Só que, como vimos anteriormente, essa verdade está oscilando entre a interpretação da pessoa e os acontecimentos.

Na teoria da gestalt, o todo é maior que união das partes. E é por isso que não podemos ter conhecimento da mensagem central de uma autobiografia somente somando as experiências da pessoa. Existem nesse contexto propriedades que ultrapassam as experiências somadas. E é por elas que podemos encontrar a mensagem central nos escritos autobiográficos.

Agostinho nas Confissões procura passar uma mensagem de salvação. Para isso ele mostrou os seus percursos e acrescentou a essa obra suas reflexões sobre o $\mathrm{mal}^{72}$, sobre a memória ${ }^{73}$, sobre as tentações ${ }^{74}$ e sobre 0 tempo $^{75}$. Fica aí então a seguinte pergunta: Por que ele quis colocar essas reflexões no meio da sua autobiografia? Ora! Não é por acaso que Agostinho fala desses assuntos nessa obra. Existe um ponto central entre esses assuntos, que é proposta de "se confessar". Para apresentá-la foi necessário mostrar primeiramente o que é o mal: Para Agostinho o mal é uma ação do homem que possui graus inferiores de ser perante a Deus. Logo depois foi preciso falar sobre a memória: Precisamos nos lembrar dos nossos erros para nos confessar. Depois das tentações: Aquilo que provoca o nosso erro. E por último o tempo: período em que ocorre a lembrança dessas manifestações. Ou seja, na sua gestalt esses temas são os elementos que permitem que a sua mensagem central sobressaia - a "ação de se confessar ". Todos esses assuntos que constituem essa proposta. Essa é a sua gestalt.

Rousseau nas suas Confissões quer descrever os seus sentimentos para se defender do desagravo e da injúria dos outros. Entre as suas minuciosas narrações encontramos muitos trechos românticos onde ele mostra os seus sentimentos alegres e a sua tranqüilidade em estar na natureza. Ele mostra a corrupção que sofreu ao enfrentar os desafios sociais. A sua mensagem central é a de que a sociedade cria egoísmo, cobiça e possessividade no homem que veio virtuoso da natureza. Sua gestalt usa a educação e a política como elementos para constituir essa mensagem.

\footnotetext{
72 Livro VII - Pág. 176

73 Livro X - Pág . 266

74 Livro X - Pág. 287

${ }^{75}$ Livro VI - Pág.319
} 
Descartes não possui uma concepção gestaltica da filosofia por acreditar que existe uma verdade única para cada coisa. E que essa verdade está no seu sistema. Mas isso não quer dizer que não conseguimos ver a gestalt do Discurso sobre o método. A mensagem desse discurso é a de que os problemas filosóficos precisam ser vivenciados antes de serem aceitos como verdadeiros. Que não adianta querer compreender o problema sem antes se apropriar deles:

É verdade que enquanto só me ocupei em considerar os modos de outros homens, achei também aqui, escassa razão para convicção estabelecida, e quase não encontrei menor contradição entre eles que nas opiniões dos filósofos. De forma que a maior vantagem que derivei do estudo consiste nisto, que ao observar muitas coisas, ainda que extravagantes e ridículas à nossa compreensão, ainda são por consentimento comum recebidos e aprovados por outras grandes nações, aprendi a entreter nenhuma decidida conviç̧ão com respeito a nada da verdade da qual eu somente tinha sido persuadido, por exemplo, e costume; e assim me desembaracei gradualmente de muitos erros poderosos o suficiente para obscurecer nossa inteligência natural, e nos incapacitar em grande medida de ouvir a razão. Mas depois de ter empregado alguns anos o estudo assim no livro do mundo e procurando adquirir experiência, tomei um dia a resolução de estudar também a mim mesmo e de empregar todas as forças de meu espírito escolhendo os caminhos que deveria seguir. O que me deu melhor resultado, ao que me parece, do que se nunca tivesse me afastado nem de meu país, nem de meus livros. ${ }^{76}$

E Nietzsche reúne todas as suas obras para afirmar a sua mensagem central no Ecce Homo, que é a da busca da saúde ao invés da moral cristã:

Em lugar da saúde a "salvação da alma" - isto é, uma loucura circular entre convulsões de penitência e histeria de redenção! A noção de "pecado" inventada juntamente com o seu instrumento de tortura, a noção de "livre arbítrio" para confundir os instintos, para fazer da desconfiança frente aos instintos uma segunda natureza! Na noção de "desinteressado", de " negador de si mesmo", a verdadeira marca da decadence, a sedução do nocivo, a incapacidade de encontrar o próprio proveito, a autodestruição, convertidos no signo de valor absolutamente, no "dever", na "santidade", no "divino" no homem! Por fim - é o mais terrível - na noção do homem bom a defesa de tudo o que é fraco, doente, malogrado, que sofre de si mesmo, tudo o que deve perecer - , contrariada a lei de seleção, tornaria um ideal a oposição ao homem orgulhoso, que vingou, que diz Sim, que está seguro, que dá garantia do futuro - este chama-se agora o mau ... e nisso tudo acreditou-se como moral! ${ }^{77}$

\footnotetext{
${ }^{76}$ Pág. 19

${ }^{77}$ Ecce Homo - Pág 117
} 
Por meio de suas Gestalten eles querem mostrar a sua visão pessoal dos acontecimentos. E para poder compreendê-las é preciso unir as suas experiências cardeais para encontrar o significado das suas reflexões. E a partir daí encontrar a conclusão que foi elaborada sobre a existência em acordo com os seus depoimentos.

Em uma abordagem gestaltica, o que importa não é tanto a veracidade das informações, mas, sobretudo, o "como" a pessoa organizou os elementos. Assim como para o "Pacto", como mencionei anteriormente. Essa abordagem mostra que as autobiografias são obras que possuem a sua própria identidade. Que são muito mais do que obras referenciais que possuem valor histórico, psicológico e sociológico. 


\section{Questões Meta - filosóficas}

"O problema não é, pois, o de não sabermos o que seja filosofia, mas de sabê-lo demasiado. Eu gostaria de poder recuperar aquele âmbito onde a filosofia não consegue ser definida com tanta precisão, onde ela ainda é um problema."

Julio Cabrera ${ }^{78}$

Ao longo desta monografia, vimos que os escritos autobiográficos são excelentes referências para conhecer uma cultura e a relação das pessoas com ela. Vimos que elas são escritas para cumprir uma necessidade e que não são uma mera apresentação de uma pessoa. E vimos que existe uma gestalt na sua formação. Resta agora saber se é possível considerar a autobiografia como um estilo de se fazer filosofia? E quais são, afinal, as demarcações da prática filosófica?

Creio que o que existe de filosófico nessas obras é que eles procuram, por meio do exemplo, sair de uma experiência singular para o pensamento universal. Sabemos que uma obra filosófica possui um problema filosófico para resolver (ou ao menos para tentar resolver). E que o que as diferenciam de outro tipo de obra é que elas querem resolver problemas que são considerados como problemas filosóficos. E que esses problemas estão relacionados a questões que são consideradas como questões universais.

Nas autobiografias analisadas, eu consegui perceber que os filósofos mostram as suas experiências singulares para refletir (de certa maneira) sobre a existência. Sobre o existir! Por meio da exploração de si, eles escrevem suas trajetórias para transmitir uma mensagem que não é necessariamente uma mensagem para si mesmo ou para uma pessoa específica. Eles querem de alguma forma alcançar o universal pelo particular. Alcançar o que existe em comum na experiência humana usando como referência a própria vida. E ao mesmo tempo mostrando que viveram vidas únicas. Utilizam-se do campo comum que é a existência para suprir as suas necessidades (confissão,

\footnotetext{
${ }^{78}$ Júlio Cabrera - "Diário de um filósofo no Brasil” Pág. 12
} 
justificação e invenção de um novo sentido) e para trazer seus questionamentos.

Nesses escritos fica claro que o sentido da vida é a principal questão filosófica de uma autobiografia. O sentido da existência entra jogo em cada momento que o autor questiona o significado da existência. Ele mostra as suas experiências próprias (nascimento, passagem pelo tempo, sexualidade, dor, perdas, etc.) pelas quais todo ser humano participa para procurar encontrar um sentido para a existência. E a procura desse sentido é a questão fundamental de todo ser humano. Elas não podem ser consideradas somente como obras de caráter subjetivo, porque de alguma maneira elas procuram objetividade no mundo. E o maior desses objetivos é sobre o sentido da vida.

Podemos dizer que quando Rousseau, Agostinho, Descartes e Nietzsche escreveram as suas autobiografias eles usaram um estilo (maneira) de fazer filosofia. Uma maneira de mostrar as suas reflexões sobre a existência e o existir. E isso mostra que a autobiografia é um estilo de se fazer filosofia, que carrega uma visão da existência que, mesmo sendo particular, procura por meio das experiências comuns e das questões sobre o sentido da vida alcançar o universal. Ou seja, a obra autobiográfica é uma obra filosófica por ser uma escrita que não fala só sobre a vida de uma pessoa, mas paralelamente sobre a vida e suas inúmeras questões. Mesmo que a Gestalt oferecida pelo autor não seja aceita por todas as pessoas.

O ser no mundo já é suficiente para levar as pessoas a filosofar através de uma visão mais romântica de filosofia, como afirma Júlio Cabrera:

Num primeiro pensamento, filosofar poderia ser visto, num viés um tanto romântico, como a maneira fundamental de instalação do homem no mundo, uma maneira insegura, temerosa, ignorante, insatisfeita, desejante e incompleta. Pode-se vincular o filosofar com o desamparo da finitude, seja qual for o âmbito em que a reflexão se manifeste, seja na filosofia da Matemática ou na Filosofia da existência. Nesta visão, o caráter filosófico não se adquire mediante a apropriação dos tecnicismos do pensamento, mas com o próprio ser no mundo. $\mathrm{E}$, de acordo com ela, todos somos filósofos. Num segundo pensamento, porém, nem todos somos filósofos, apenas aqueles seres perguntantes que não só vivem as a sua inseguranças insatisfeitas mas as transformam numa forma de sensibilidade para o esclarecimento. $O$ filosofo não será apenas o humano desamparado e incompleto, mas aquele humano que ousa 
lançar-se sobre seu desamparo e incompletude com paixão reflexiva, com menos medo da loucura que da mediania. ${ }^{79}$

Se levarmos em consideração o primeiro momento da atividade filosófica que foi mostrado por Cabrera, poderemos dizer que as autobiografias são maneiras de filosofar por si mesmas. Mesmo que não contenham tratados ou métodos para grandes problemas filosóficos.

O que diferencia uma autobiografia de uma pessoa qualquer de uma autobiografia de um "Grande Filósofo" é somente a qualidade das reflexões que são passadas. O Filósofo vai trazer reflexões mais refinadas para a questão do sentido da sua existência e da existência. Ele vai procurar sair do senso comum para tirar as suas próprias conclusões. Procurar conhecimento do vivenciado e se aprofundar nele de maneira mais reflexiva e original.

O filósofo, como afirma Cabrera, transforma a sua sensibilidade sobre a existência em uma forma de esclarecimento com ousadia e originalidade. Suas reflexões são mais profundas e mais ousadas do que as das outras pessoas que escrevem autobiografias. $O$ que não quer dizer que as outras autobiografias não possam ser filosóficas. O que as diferencia é o grau de profundidade das reflexões que são apresentadas. O estilo ainda é o mesmo.

Isso tudo me levou a pensar sobre a demarcação da filosofia, a buscar saber qual maneira (estilo) de se fazer filosofia é considerada. Ao que me parece, não existe nada que obrigue a filosofia a ser feita somente de uma só maneira. Só que ao longo desses anos em que estudei na universidade eu pude constatar que os diferentes estilos (Autobiografia, aforismos, romances, ficções, contos, etc.) eram pouco ou quase nunca estimulados pelo professores. O método estruturalista de análise rigorosa e precisa dos textos acabou por excluir outros estilos de prática filosófica, o que tem por efeito limitar a exploração das potencialidades. Os possíveis talentos estilísticos do aluno são obscurecidos por um método que procura padronizar os trabalhos. Raramente seriam aceitos trabalhos como poesias, ficções, romances, pinturas, autobiografias ou até mesmo músicas que possuam conteúdo filosófico. Trabalhos com um estilo alternativo de fazer filosofia ou ao menos de

\footnotetext{
${ }^{79}$ Júlio Cabrera - "Diário de um filósofo no Brasil" Pág. 13
} 
entendê-la. Com certeza diriam que ele está no curso errado e que nesse curso todos os trabalhos deveriam ser feitos da mesma maneira, ou seja, no mesmo estilo.

O aluno é excluído para o que o método aconteça. Suas experiências e a sua visão sobre os problemas apresentados não fazem a mínima diferença para esse método. O que importa é saber como analisar um texto filosófico sem sair dele. O "eu" do aluno é apenas o instrumento pelo qual a análise do texto acontece. A maioria dos professores acredita que a sua visão não é suficiente para pensar o problema em questão e por isso acham melhor ele pegar soluções emprestadas. Mas a diferença que existe nesse contexto é que a visão é da pessoa e isso já é digno de mérito. No final do curso nós encontramos o conhecimento adquirido, o diploma da instituição e a expectativa do entrar no mercado de trabalho. Só que a criatividade e a possibilidade de fazer diferente foram perdidas.

Apesar de não existir nenhuma demarcação obrigatória sobre os estilos de fazer filosofia nós vemos que eles não são estimulados. Os diferentes estilos só são usados como referencia para analise filosófica. Ou seja, estudamos os tratados dos filósofos, as suas autobiografias, os seus aforismos e os seus poemas, mas não podemos fazer o mesmo ${ }^{80}$ que eles.

Ao que me parece os diferentes estilos e a visão pessoal do aluno não são bem vindos no curso de filosofia. São somente poucos professores que estimulam o aluno a pensar por si e a querer desenvolver outros estilos ${ }^{81}$.

Não estou querendo dizer que qualquer tipo de trabalho deveria ser aceito como trabalho filosófico. Até porque os professores precisam de um critério para poder avaliar os alunos. Só que acho importante ver o que está sendo deixado de lado quando escolhemos somente uma forma de avaliar as pessoas. Podemos estar empobrecendo o espírito humano como mostra o Professor Armijos:

\footnotetext{
${ }^{80}$ Idéias encontradas no livro "O diário de um filosofo no Brasil" de Júlio Cabrera.

${ }^{81}$ Em 2010 eu fiz uma matéria que tratava de autobiografias onde a avaliação final era a escrita da própria autobiografia. Oportunidade rara e quase única em um departamento de filosofia.
} 
Isso nos leva ao nosso problema inicial e é mais um argumento que refuta a idéia da inferioridade filosófica das línguas. O ser humano tem, naturalmente, a tendência a filosofar. Isso está baseado na sua própria curiosidade natural, naquele afã do saber que se mostra nas pessoas desde muito cedo. Há razões culturais, religiosas, ideológicas e históricas que impedem que essa curiosidade seja orientada para a produção de filosofia e ciência. Ou a sociedade possui as instituições que estimulam a produção de cultura, como a dos mecenas da Renascença, ou as que coíbem como a intolerância religiosa e o autoritarismo acadêmico.

O ser humano nasce naturalmente para a filosofia, são certas instituições que dela o afastam. O espírito humano é rico em intuições profundas, é o meio que o empobrece ou o estimula... ${ }^{82}$

O estilo autobiográfico mostra que é possível pensar questões filosóficas falando em primeira pessoa. Que é possível pensar essas questões de outra maneira e que podemos filosofar assim como os filósofos clássicos. Pois, assim como eles nós participamos de experiências comuns que estão sendo oferecidas pela existência. $E$ essas possibilidades não mostram o lado alternativo da filosofia, mas sim, a sua verdadeira face. Sua característica pluralista e diversa que pode ser encontrada em quase todo tipo de atividade humana.

\footnotetext{
${ }^{82}$ Armijos "De como fazer filosofia sem ser grego, estar morto ou ser gênio " Pág.20
} 


\section{Referencias bibliográficas}

1. AGOSTINHO DE HIPONA. Confissões. Os pensadores, SP. 1999

2. DESCARTES René. O discurso sobre o método. Editora vozes. Petrópolis RJ.1999

3. NIETZSCHE Friedrich. Ecce Homo. Companhia das letras, $\mathrm{SP}, 2000$

4. ROUSSEAU, Jean Jacques. Confissões. Edipro, Bauru, SP, 2008.

5. MOTTA, Marly Silva da. O relato biográfico como fonte para a história. Vidya, Santa Maria (RS), n³4, p.101-122, jul-dez, 2000

6. ROSENTHAL, G. A estrutura e a gestalt das autobiografias e suas conseqüências metodológicas. In: FERREIRA, M. de M. \& AMADO, J. (orgs.). Usos e Abusos da História Oral. Rio de Janeiro: Editora da Fundação Getúlio Vargas, 1996

7. CABRERA,Júlio. O diário de um filosofo no Brasil. Unijui. RS. 2010

8. CALLIGARIS, C. Verdades de autobiografias e diários íntimos. Estudos Históricos, Rio de Janeiro:Ed. Fundação Getúlio Vargas, v. II, n. 21, 1998.

9. ARMIJOS Palácios Gonzalo. De como fazer filosofia sem ser grego, estar morto ou ser gênio. Editora UFG< Goiânia, 2000 (20 impressão).

10. KOHLER, W. Psicologia da Gestalt. Itatiaia. Belo Horizonte, 1980.

11. SHIFFIMAN, Harvey Richard. Sensação e Percepção. Ed. LTC. Rio de janeiro. 2005

12. PEREREIRA, Ligia Maria Leite. Algumas reflexões sobre histórias de vida, biografias e autobiografias. - Este texto foi apresentado na Mesaredonda "História Oral e as tramas da subjetividade" realizada no III Encontro Regional Sudeste de História Oral, Mariana, 12 a 14 de maio de 1999. Encontra-se no seguinte endereço eletônico: http://revista.historiaoral.org.br/index.php?journal=rho\&page=article\&op=viewFil e\&path\%5B\%5D=26\&path\%5B\%5D=20- Ultimo acesso em 01 /01 /2011 